\title{
Political Accountability In Botswana's Liberal Democracy: A Critical Appraisal
}

\author{
Batlang Seabo \\ Department of Political and Administrative Studies \\ University of Botswana \\ Mogopodi Lekorwe \\ Department of Political and Administrative Studies \\ University of Botswana \\ Kabelo Moseki \\ Department of Statistics \\ University of Botswana
}

\begin{abstract}
Botswana has been regarded as a frontrunner in democratic practice and good governance, yet accountability, which is one of the cornerstones of a liberal democracy, is in a deficit. While on one hand Batswana express popular preference for accountability and demand leaders to account, on the other hand there is a short supply of accountability from elected officials and parliament. This state of affairs is at odds with modern democratic practice and is clearly indicative of an accountability deficit for a country that is considered the oldest democracy on the continent. The article argues that elected leaders and parliament should be accountable in order to enhance the quality of Botswana's democracy.
\end{abstract}

Key words: Botswana, Democracy, Vertical Accountability, Horizontal Accountability

\section{INTRODUCTION}

What do Batswana think about accountability on the part of their leaders? Is the mere casting of the ballot in every election sufficient to hold elected representatives accountable? Are Batswana active citizens who demand accountability from their leaders or passive voters who simply delegate?

These questions are pertinent to be explored for a country that is considered one of Africa's oldest democracies that has enjoyed democratic stability and good governance for five decades. Admittedly so, these accolades are much deserved, because when other African countries (Malawi, Kenya, Zambia, Tanzania, Mozambique Ethiopia) abolished multi-party systems and replaced them with one party system, Botswana maintained multi-party system and has held uninterrupted free and relatively fair elections since independence. However, it is worth noting that democracy should be more than just the conduct of elections and having multi-party system. In a well-functioning democracy, the expectation is that leaders have an obligation to account to voters. And while elections are important to hold leaders accountable, they alone are not a sufficient measure of accountability particularly given their infrequent periods. Elections are not helpful in the assessment of the performance of leaders in between electoral intervals. Politicians make promises in order to be elected, only for them to fail to act according to the wishes of the voters. The all important question, therefore, is whether 
Batswana demand leaders to account for their failures or not, and whether they think that leaders actually account.

Debates on accountability in Botswana seemingly a note worrisome deficiency in institutional accountability, what 0' Donnell (1994) refers to as horizontal accountability. In fact, as we show in this paper, research on institutional checks and balances in Botswana abound, much to the neglect of citizens' views on whether or not they secure political accountability.

Bratton and Logan (2006) write that the emerging literature on accountability tends to recognize that individuals' underlying attitudes and expectations do matter. This, therefore, implies that scholarship should move away from the conformist and descriptive analysis of accountability to a much more empirical approach. In this respect citizen's attitudes and perceptions are pertinent.

Using Afrobarometer public opinion survey, this paper examines citizens' views on demand and supply of horizontal and vertical accountability. The central argument of the paper is that Botswana's democracy suffers an accountability deficit as perceived preference and demand for accountability exceed perceived supply. This is not only an indictment on the voters but also bodes ill with known precepts of democratic practice.

The paper proceeds as follows: In the section that follows, we briefly review the literature on accountability in Botswana, followed by theoretical perspectives on political accountability. We then turn to methodology used. The last but one section presents results and discussions. Then the last section is the conclusion.

\section{LITERATURE REVIEW}

Botswana has maintained a notable record of democratic practise that is celebrated in Africa and the rest of the world. Molomo $(2000,95)$ notes that "while white minority rule and one party regime eclipsed other countries in the Southern African region, Botswana enjoyed a stable multi-party democracy". Periodic elections have also been held since independence in 1966, with observers hailing them as free and relatively fair. Sebudubudu and Osei-Hwedie (2006: 35) write that "Botswana has been portrayed a shining example primarily because of relatively free and fair elections, political tolerance, multiparty competition, the rule of law and universal franchise."

The country has also progressed on the economic front, recording high levels of economic growth in the 1970s and good overall development.

As Botswana's democracy approaches a fifth decade, it is important to pause and reflect on a fundamental aspect of the country's democracy, political accountability. Research on accountability typically focuses more on horizontal accountability, that is, institutional checks on the powers of government agencies. This body of literature (Osei-Hwedie and Sebudubudu, 2006; Maundeni, 2008; Bodilenyane, 2013; Lotshwao and Botlhale, 2014) addresses the relationship between parliament and the executive, that is, mechanisms parliament uses to hold the executive accountable, the role of corruption fighting institutions as well as the role of Office of Ombudsman. Over and above the roles of these oversight institutions, research has attempted to assess their effectiveness in exercising accountability and the conclusions reached often point to a dismal record. For instance, Botswana's parliament is weak because of its lack of independence from the executive and lack of capacity which impedes its law making role. As Botlhale and Lotshwao (2014:42) observe, "among others, the parliament of Botswana neither has an independent budget nor does it hire its own staff. Instead, it depends 
on the Office of the President and Directorate of Public Service Management (DPSM) for the budget and personnel respectively." Perhaps the most succinct description of parliament's ineffectiveness is offered by Sebudubudu and Osei-Hwedie (2006:38) when they state that: Although law making is one of its functions, the Botswana parliament has been unable to initiate laws, instead it merely approves government legislation. Private members' bills have not been forthcoming since independence, except for one, several years back, primarily because the process of drafting legislation is dependent upon one person, the attorney general, who is also the government's lawyer (interview MPs 2004). This suggests that lack of legal skills for drafting legislation constrains their law making function. Similarly, in spite of being sovereign, parliament rarely challenges the government's budget in spite of lively debate and minor modifications by the backbench and opposition members

This state of affairs is clearly at odds with representative democracy and renders parliament ineffective and obsolete. Calls for reforms to enhance the effectiveness of parliament and grant it independence have been made by all and sundry to no avail. For instance, the opposition has been advocating for the independence of parliament from the executive and the former Speaker of the Parliament Dr. Margaret Nasha made attempts to reform parliament in order to make it independent and effective, but her efforts never saw the light of the day. The dominance of the Botswana Democratic Party in parliamentary committees also stifles the functioning of committees.

Established by an Act of parliament of 1995, the Directorate on Corruption and Economic Crime (DCEC) is charged with the mandate of investigating corruption in the public sector. However, the effectiveness of the corruption busting institution has come under attack for its lack of independence and selective approach in investigating and prosecuting. The DCEC has often been criticized for failing to address grand corruption or cases involving highly placed influential figures, the so called "big fish" and only going after "small fish". A strong view is that the rich and the powerful members of society are not investigated, and in a few cases where they are investigated, they are acquitted (Mokgatle \& Molefhe, 2008).

Charged with investigation of cases of maladministration, the Office of the Ombudsman has similarly been criticized for failing to compel enforcement of its decisions. Mpabanga (2008) cites the case of the use of Botswana Defence Force aircraft by the then vice president, Ian Khama, noting that the recommendations of the Ombudsman report could not be implemented because the Office of the President refused to accept them.

The above cited cases illustrate the extent to which there is weak institutional accountability in Botswana.

However, as we noted earlier, research is skewed towards horizontal accountability and rarely examine vertical accountability. According to Bratton and Logan (2006:3), "this preoccupation arises partly out of a bias towards formal institutions and relationships, as well as a tendency to focus on traditional means of enforcement, as compared to the more varied and often ad hoc nature of popular efforts to secure accountability from below."

But vertical accountability is also an integral part of any functioning liberal democracy. Typically, elections are one measure of ensuring vertical accountability in the sense that voters have certain expectations from their representatives. As Bratton and Logan put it, "an implicit assumption is that competitive electoral politics automatically unleash public desires and expectations for answerability." (2006) 
For Barei (2008), MPs may not be returned to office if the electorate perceives them as poor performers. In this way, elections serve the purpose of holding leaders accountable. And as we have noted earlier, Botswana has performed remarkably well in holding periodic and peaceful elections. But, elections are not an effective mechanism of holding leaders accountable, in the sense of citizens' routine exercise of demanding answers from leaders. Immediately they assume office, political representatives are compelled, and must at any point be held responsible for their actions by those they represent, as a matter of principle. Unfortunately, for much of Africa, elections have not in the main served this purpose of holding leaders accountable, more than recycling same unaccountable politicians. Botswana is no exception to this trend, where elections have been reduced to a caricature of putting "new wine in old bottles."

The above discussion indicates serious loopholes in Botswana's liberal democracy, insofar as holding leaders accountable is concerned.

It has now become ever more imperative in Botswana for citizens to routinely demand answers from their representatives, especially when allegations of corruption and mismanagement by elected officials frequently make news headlines, and institutional mechanisms of horizontal accountability are seemingly incapable of bringing leaders to book.

On this basis, we note that research has neglected the underlying citizens' attitudes towards accountability by leaders and institutions. For this reason, Bratton and Logan (2014) state that there is increasingly some recognition in the literature on accountability that individuals' underlying attitudes and expectations do matter.

Research on this aspect is lacking and worrisome for a country that is celebrated as an icon of good democratic practice in Africa.

\section{Theoretical Perspectives on Liberal Democracy and Political Accountability}

A liberal democracy is defined as a political philosophy by which people have inalienable rights to power and free elective process of their country. In other words, a liberal democracy is a political system characterized by a free election, and political decision made by an independent legislature, a multiple political system, and an independent judiciary. In a liberal democratic system, people have the right to voice their concerns in the decision making process of their country with application of a majority rule and vote a candidate they wish to run for political office. In other words, a liberal democracy is a democracy of the people and for the people.

Typically, liberal democracy gives the citizens the overall strategy to improve the political economy of their country through a better government. Under a liberal democratic rule, people have the right to vote and participate in civil engagement to protect their rights. By actively participating in the government activities, people are able to protect themselves from the ruling elites. By participating in political activism, people are able to protect their civic rights from a corrupt government (Mulgan, 2003).

In a democratic system, political leaders can be held accountable for the misdeeds carried out when in office (Schmitter, 2007). Political accountability refers to the way political parties, citizens, parliaments as well as other political actors provide reward, feedback or sanctions to officials enacting public policy. Typically, in a well- functioning democracy, accountability is able to provide incentives for government for the interest of all citizens. 


\section{Political Accountability}

Accountability, as already stated, is one of the cornerstones of a liberal democracy. As Bratton and Logan (2006) write, the obligation of political leaders to answer to the public for their actions and decisions - the obligation of accountability - is a cornerstone of a well-functioning democratic system.

According to Schmitter (2007), in terms of political accountability, each citizen has the same rights and obligations, i.e. to be informed about prospective actions, to hear the justification for them and to make a judgment about how they were performed. This ensures that political leaders do not abuse their powers in the exercise of their responsibilities. In the same vein, Logan and Bratton (2006) maintain that political accountability checks the power of political leaders to prevent them ruling in an arbitrary or abusive manner, and helps to ensure that governments operate effectively and efficiently.

In a modern democratic government, actors in a public domain are responsible for making decisions regarding the common goods, and through several methods are held accountable for their conducts (Peter, \& Authur, 2012). Borowiak (2011) argues that accountability is an instrument to control governing authorities, and effectiveness of liberal democracy depends on a meaningful accountability. According to Schmitter (2007), accountability is first a relationship between two sets of actors (actually, most of it is played out not between individuals, but between organizations) in which the former accepts to inform the other, explain or justify his or her actions and submit to any pre-determined sanctions that the latter may impose.

O'Donnell, (1998) argues that horizontal accountability is very critical for a smooth running of a democracy. Horizontal accountability is defined as the existence of state agencies, factually willing, legally empowered and enabled to take actions on impeachments or criminal sanctions on state political actors (Chen \& Hsu, 2014). For Bratton and Logan (2014) horizontal accountability is constitutional checks and balances on the political executive from other institutions of government - like the legislature and the courts.

Typically, the state agencies are responsible for the horizontal accountability. Moreover, the non-state actors such as party secretariats, media organizations, business associations, trade union confederations, large capital firms and mass social movements are capable of exercising the horizontal accountability. In a liberal democratic country, political parties play a critical role in enhancing or subverting the horizontal accountability. In a presidential system of government, the most important aspect of horizontal accountability is separation of powers and checks and balances. Nigeria is one of the examples of a developing country that practices horizontal accountability because the country is practicing the presidential system of government. The separation of powers and checks and balances are clearly entrenched in the constitution where the executive is separated from the legislature and both the executive and legislature are separated from the judiciary. The principle of checks and balances is another aspect of horizontal accountability where each branch of government checks on the power of other branches of government to limit their powers. For example, the congress can remove the president through impeachment while the judiciary can declare the action of congress and executive acts by president as unconstitutional (Samarasinghe, 1994). Moreover, the executive president can veto the law passed by the congress.

Despite the benefits of horizontal accountability for the effective implementation of a liberal democratic system, the principle of horizontal accountability is lacking in many developing countries that practice liberal democracy. While some developing countries hold elections 
regularly, however, these countries have intermittent or weak horizontal accountability. O'Donnell, (1998) points out that many Latin American countries have recently become politically democratic. For example, Uruguay, Costa Rica, Columbia, Venezuela and Chile lack the concept of horizontal accountability. These countries have been characterized by personal rule, authoritarianism and high levels of corruption because of weak institutions. Moreover, freedom of speech and free press that permit citizens to voice their social demands are weak in many developing countries. While horizontal accountability is very effective for a successful implementation of liberal democracy, at the same time a weakness of horizontal accountability can correspond to a weakness of liberal democracy. 0' Donnell attributes this weakness to weak institutions that are subjected to the whims and caprices of an authoritarian president. Besides institutional accountability, voters can directly hold leaders accountable, what O’Donnell refers to as vertical accountability.

Typically, free and fair election is the essential feature of vertical accountability. As Bratton and Logan (2014) put it, vertical accountability comes from below and it is exercised mainly through elections, which provide citizens with intermittent opportunities to reward or punish incumbent leaders.

African countries that practice liberal democracy use periodic elections to allow political competition, and this has become a norm in the African region. Similar to many developed countries that use election process to hold political actors accountable, some developing countries in Africa have just started using free and fair election as a political weapon to hold political actors accountable (Speijcken, 2011). A recent Nigerian presidential election in 2015 is a good example of how people have used the open and free ballot system to vote out the incumbent government out of power. In Nigeria, the PDP (People's Democratic Party) had controlled the Nigerian leadership position for more than two decades. However, the PDP rule was characterized by high-profile corruption, and series of civil insurgence that nearly tore the country apart. When the presidential election took place in May 2015, people voted out the PDP and voted in the APC (All Progressive Congress) as the new government. The outcome of the presidential election in Nigeria reveals that the people's vote is one of the effective tools to hold political institutions accountable.

In the case of Botswana, as noted earlier, periodic elections have been held but it remains questionable whether they have effectively ensured vertical accountability. And as we noted earlier, having strong political parties and regular elections may not be sufficient to hold political leaders responsible for their actions. Because elections are held on an interval of, commonly five years, they are not adequate to gauge the performance of political leaders during their term of office. The five year interval period of elections is too long to punish underperforming politicians especially that voters do not have the power to recall a mediocre representative. Schmitter (2007) captures this insufficiency of elections thus; "It is one thing regularly to hold "free and fair" elections; it is quite another to ensure that these elections will be uniquely capable of holding the winners accountable". For Logan and Bratton (2006), elections are not enough to hold leaders accountable because of infrequent opportunities to cast a ballot, which is commonly after 5 years for parliament and presidential elections.

It is imperative that leaders are subjected to scrutiny even during their term of office.

Bratton and Logan (2014:2) write that "in all democratic regimes, citizens can seek vertical accountability on a sustained basis between elections by making regular claims against elected leaders through political parties, civic associations and the mass media" 
On the basis of this theoretical framework, we examine the extent to which citizens demand accountability and perceive the supply of accountability, both horizontal and vertical. Our analysis is based on Richard Rose and others' application of demand and supply economic language to the concept of accountability. According to Bratton and Logan (2014), voters demand accountability from politicians by making them answer for their official deeds, and accountability is determined by the degree of transparency of government. But since politicians tend to prefer to insulate themselves from being accountable, demand for accountability would exceed supply.

For this reason, Bratton and Logan conclude that "everything equal, the power differential between principals (voters) and agents (elected leaders) can be expected to incur a deficit of political accountability in which demand usually exceeds supply." (2014: 2).

\section{METHODOLOGY}

In this article we use Afrobarometer data covering three rounds (2008/2014/15) to analyse accountability deficit in Botswana. Afrobarometer is an African-led, non-partisan research network that conducts public attitude surveys on democracy, governance, economic conditions, and related issues across more than 30 countries in Africa. Five rounds of surveys were conducted between 1999 and 2013, and Round 6 surveys were concluded in 2014-2016. Afrobarometer conducts face-to-face interviews in the language of the respondent's choice with nationally representative samples of between 1,200 and 2,400 respondents.

The Afrobarometer team in Botswana, led by Star Awards (Pty) Ltd, interviewed 1,200 adult Batswana in June and July 2014. A sample of this size yields results with a margin of error of $+/-3 \%$ at a $95 \%$ confidence level. Previous surveys have been conducted in Botswana in 1999, $2003,2006,2008$, and 2012.

\section{Importance of elections}

\section{RESULTS AND DISCUSSIONS}

Botswana has consistently been applauded as one of the few African countries to show commitment to upholding democratic principles. Thus the country has consistently held uninterrupted elections since independence in 1966. This is supported by the fact that Batswana like other Africans overwhelmingly believe that they can use elections to hold leaders accountable (figure 1). 


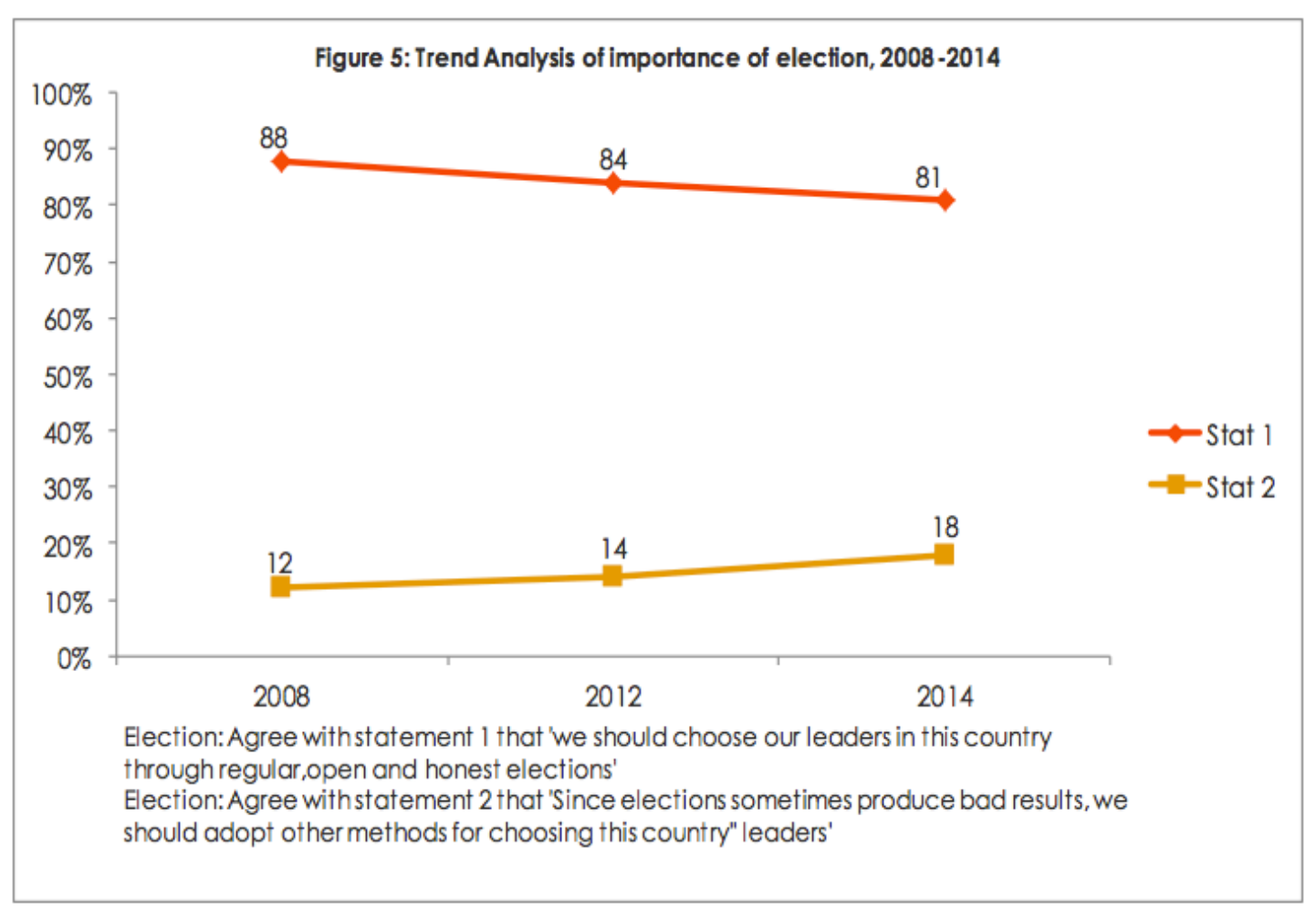

From the figure above, there is clear observation that Batswana yearn for choosing leaders in this country through regular, open and honest elections. The trend displayed above shows a declining pattern of perceptions of citizens towards elections over the years. The people of this country wish to see a robust system in which they exercise their right of choice for leaders. Apparently since 2008, the surveyed individuals scored above $80 \%$ that they prefer a situation where their leaders are chosen through regular, open and honest elections.

\section{An Accountable Government: Preference for accountability by Batswana}

In a democracy it is expected that citizens are more likely to support democratic values and practices (Dalton, 2013). In pursuit of democratic values, citizens have to contend with a government that either takes swift decisions but not accountable, or one that moves with caution ensuring that they are accountable. Respondents were asked to choose between two statements: Statement 1: It is important to have a government that can get things done, even if we have no influence over what it does; Statement 2: It is more important for citizens to be able to hold government accountable, even if that means it makes decisions more slowly.

Of the Batswana surveyed in the Afrobarometer research in 2012, nearly a quarter (24 percent) have preference that the government can get things done, even if they have no influence over what it does, but on the contrary, a clear majority of almost three quarters (74 percent) of the respondents prefer that the government must be held accountable, even if that means it takes decisions more slowly.

Things changed in 2014, when now citizens begin to prefer the government get things done without them knowing what it does. Their perception is seen in the last round of Afrobarometer survey. Now one third of those who got enumerated are of the view that the government can get things done with no idea of what it does. Well, citizens seem to be giving up on government accountability to them. Their preference for government accounting to them has significantly declined to 65 percent. This is a paradox because as the media continues exposing many scandals and allegations of corruption, the expectation is for citizens to see the virtues of political accountability. As we have established before that accountability is one of 
the cornerstones of a liberal democracy, the expectation is for citizens to know what government does and hold it responsible but the decline in holding government accountable runs at odds with virtues of accountability.

\section{Vertical Accountability}

Vertical accountability is the process by which citizens, the media and other civil society groups seek to enforce standards and make officials respond to their concerns. The public and other organized interest groups can seek the support of elected representatives for redress and in some cases can intervene against the actions of government. O'Donnell initially defined vertical accountability in terms of elections that is "making elected officials answerable to the ballot box" (O'Donnell, 1994: 61). Simply adopting this definition falls short of helping the situation since all systems provide an opportunity to hold elections. It is, therefore, clear that the holding of free and fair elections is a necessary condition but not sufficient condition. There are a myriad of reasons which explain why the holding of elections has inherent limitations. Reasons vary from infrequent elections, failure of elections to provide sufficient alternatives to voters, lack of information to voters, representatives failing to honor their promises and the failure of elections to constantly keep elected representatives on their toes as they happen after a long period of time. Voters can also continuously demand vertical accountability in between elections through other mechanisms as joining a demonstration or using the media to air their views. The majority of Batswana are not in the habit of demonstrating against authorities to demand a service.

In most developing countries, political parties are not well developed and do not give voters a real choice. In addition, elections alone cannot hold appointed officials to account for their actions. Despite all the accolades that Botswana has been receiving from the international community as a shining example of democracy, there is a deficit between demand for vertical accountability and supply of the same.

\section{Demand for Vertical Accountability}

Within the Southern African Community (SADC) Botswana is one of the countries which show low levels of participation in the democratic process (Bratton and Logan, 2009). In other words even though mechanisms were availed to them, the majority showed little interest in taking part in the political system between elections. Thus elected representatives were not made to account for their actions except only at election time. In order to determine the extent to which Batswana demand vertical accountability from their leaders, respondents were asked; who should be responsible for making sure that once elected, legislators do their jobs? This included both Members of Parliament (MPs) and Councilors. The possible responses to this question were the executive/President, the parliament/council, their political party or the voters themselves? 
Figure 2: vertical accountability

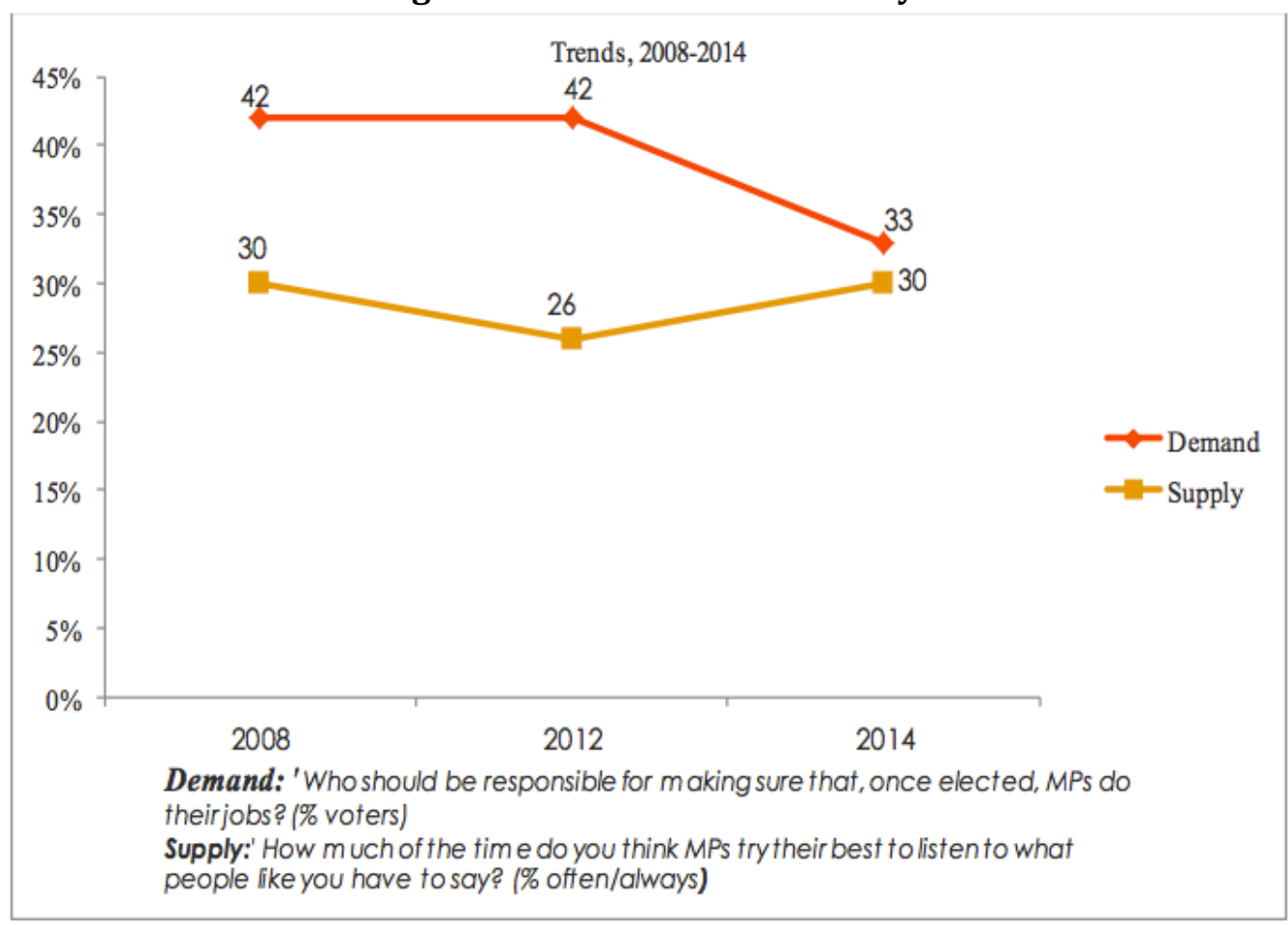

The pattern of vertical accountability seems to remain constant at 42 percent from 2008 to 2011, and declines by 9 percentage points in 2014, and this suggests that voters are beginning to retire in holding political leaders to account. The respondents also apportion some responsibility to the Executive to ensure that members of Parliament fulfil their duties as in at least 30 percent of the times from 2008 to 2014.This is followed by members of parliament holding themselves responsible standing at over 15 percent that they must monitor themselves. From the above analysis, one can infer that elections do not automatically lead to accountability because it is not supported by strong demand for vertical accountability. In our context the president seems to be receiving a substantial rating for making members of parliament carry their jobs. One would have thought that overwhelming scores go to the voters as they were showered with promises from members of Parliament during the election campaigns.

It is also interesting to note that in 2014 there was some recognition that a political party can also hold leaders accountable. Ten per cent of the respondents felt a political party should ensure that leaders account for their performance. This is not a total surprise because the survey took place before elections and a lot was happening on the ground with respect to the holding of primary elections. Politicians of all political parties were campaigning from house to house and as a result this hyped the importance of political parties.

\section{Supply of Vertical Accountability}

The quality of political leadership has been a concern for many developing countries. Many of these leaders are elected into these positions with the expectation that they would deliver on their promises. More importantly, in a democracy, it is expected that for them to be re-elected, they should satisfy their constituents. In this respect supply of vertical accountability becomes key. The key indicator of the supply of vertical accountability is, 'how much of the time do you think that members of parliament try their level best to listen to what people like you have to say?' Out of the surveyed Batswana in 2008, just 30 percent of them thought that their members of Parliament 'often or always' listen. By 2012 the figure dropped by 4 percentage 
points and scaled up to 30 percent in 2014. The pick in supply of accountability in 2014 could well be explained by the fact that 2014 was an election year in which the BDP government faced a threat posed by an opposition alliance. It, therefore, follows that in an election year, seeking to be re-elected, politicians make time to listen to voters' concerns.

Local government councillors do much better across all the rounds. In 2005, just 44 percent of the survey respondents said that councillors listened. But scores declined sharply in 2008, of which 32 percent rated councillors as leaders who listen to what they have to say. This could be so because councilors work closely with the electorates. A pick in the rating was observed in 2014 by a 1 percentage point. This means 33 percent of interviewers scored them as such.

It is, however, important to come up with mechanisms of ensuring that vertical accountability does take place. Most democratic theorists used a simplistic measure by arguing that this requires 'free, fair and regular conducted elections' (Schmitter, 2007).

\section{Horizontal Accountability}

It is an accepted view that in a democracy there are institutions which are responsible for providing horizontal accountability. These institutions among others include Parliament, the judiciary, the Auditor General, independent electoral commissions, ombudsman and anticorruption agencies (Bovens, 2007). These are relatively autonomous agencies which have the powers to call government officials or other agencies to account for their actions. In addition to this, it is also true that mutual accountability exists between agencies of equal footing.

Figure 3: Horizontal accountability

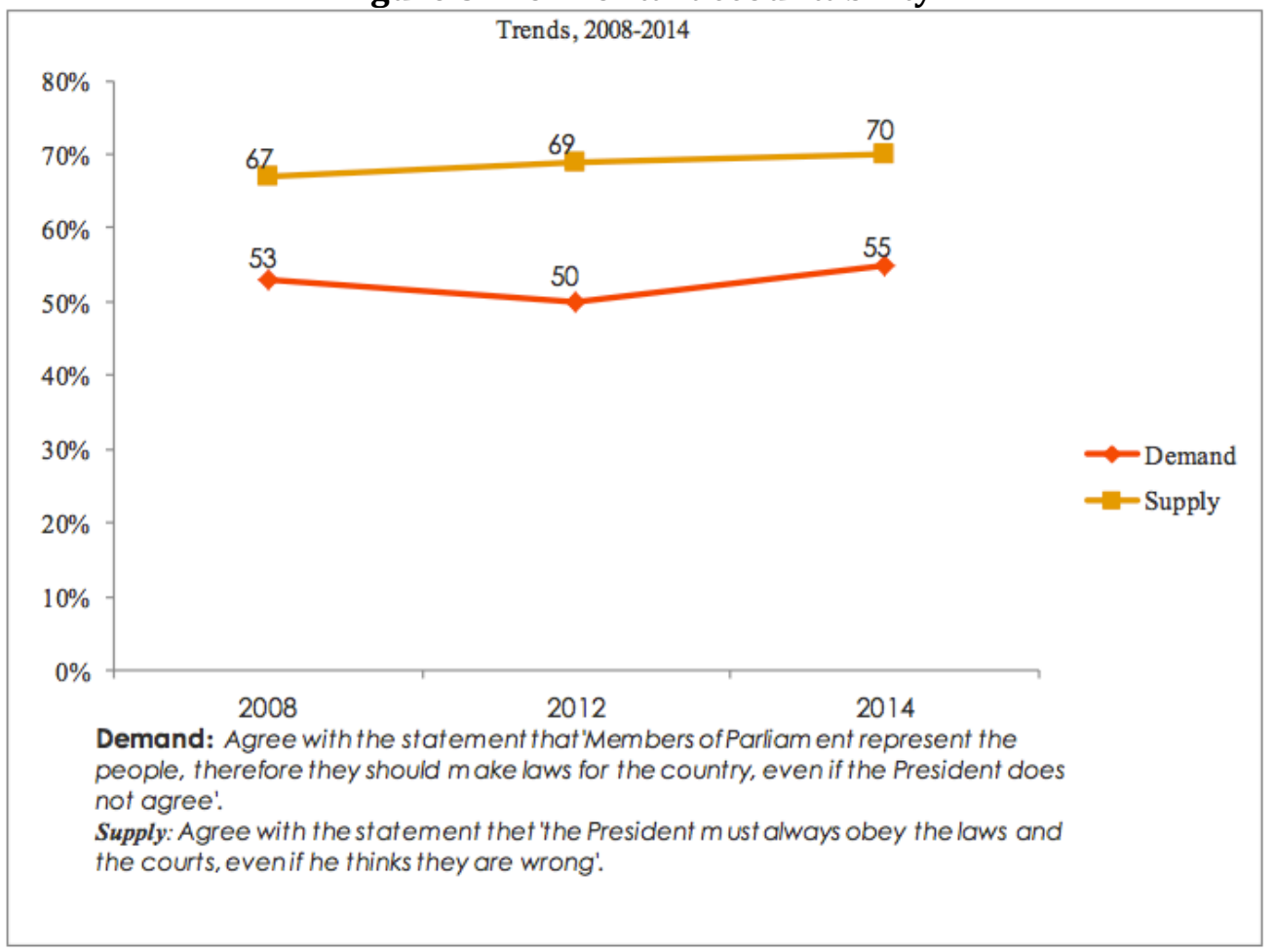

\section{Supply of horizontal accountability}

The Afrobarometer gauges the perceived supply of horizontal accountability by asking, 'which of the statements is closest to your view?', since the President was elected to lead the country, he should not be bound by laws or court decisions that he thinks are wrong and that the President must always obey the laws and the courts, even if he thinks they are wrong? The second statement is used to indicate the above type of accountability. Botswana citizens surveyed in the study registered at least two thirds majority that the president must always 
respect the rule of law and its courts across rounds. On the other hand, there are observations that two in five that support the President should not be bound by laws or courts decisions. The trend over the rounds expresses the sentiment that citizens unwaveringly believe that nobody is above the law including the head of state. We notice an increasing pattern of perceived supply of horizontal accountability from round 4 .

\section{Demand for horizontal accountability}

It is natural that once elected by people into power they expect you to deliver on your mandate. Some observations have been made over the rounds that Batswana prefer a marginally strong legislature. On average, half of the interviewers expect the Parliament to make laws rather than the President. However, a good proportion of respondents of over twenty percent especially in the last three rounds but one are disagreeable with the two statements. This poses a concern as to whether constituents really know what their responsibilities are in a democratic system of governance.

\section{CONCLUSION}

Political accountability is an essential ingredient of democracy that ought to be demanded by citizens and supplied by political leaders. While Batswana prefer an accountable government, they tend to delegate accountability to institutions of authority more than they perceive themselves responsible to hold leaders accountable. In this article, we have demonstrated that though Botswana has been showered with praises of being a shining example of democracy, accountability which is an important tenet of democracy is low. Both demand and supply of vertical accountability are below fifty percent, with supply at just thirty percent between 2012 and 2014. Things started changing in 2008 when leaders were not listening much to what the constituents were saying. Between 2012 and 2014 before elections, political leaders then were under pressure to listen to citizens' views.

The picture changes when we turn to horizontal accountability. It is true that Botswana has been recognized as one of the African countries that observes the rule of law. Clearly, citizens confirm that everybody should be subject to the laws of the country including the president. All in all, though Batswana believe that elections are an important institution to hold leaders accountable, there is clearly a deficit with respect to demanding this accountability. There seems to be a mismatch between the two and what causes this mismatch is a subject for the next research paper.

\section{References}

G, Barei, Parliament. In Transparency, Accountability \& Corruption in Botswana, (2008), Made Plain Communications, Cape Town

K, Bodilenyane, Botswana's Executive Presidency: Implications for democracy, Journal of Public Administration and Governance, 2(4), (2013), 188-201.

E, Botlhale, and K, Lotshwao, The uneasy relationship between parliament and the executive in Botswana. Botswana Notes and Records, 45. (2015).

C.T, Borowiak, Accountability and Democracy. The Pitfalls and Promise of Popular Control. London. Oxford University Press (2011)

M, Bovens, Analysing and Assessing Accountability: A Conceptual framework. European Law Journal, Vol 13(4) (2007), 447-468

M, Bratton, and C, Logan, Voters but not yet citizens: The weak demand for vertical accountability in Africa's unclaimed democracies. East Lansing/Michigan State University, Afrobarometer Working Paper, (63) (2006)

M, Bratton, and C, Logan, From Elections to Accountability in Africa? Governance in Africa, 1(1) (2014) 
W, Chen, and J.C Hsu, Horizontal Accountability in a Polarized New Democracy: The Case of Post-Democratisation Taiwan. Australian Journal of Asian Law. 15(2) (2014) 1-19.

$\mathrm{C}$, Cheung and $\mathrm{K}$, Leung, Enhancing life satisfaction by government accountability in China. Social Indicators Research. 82.3 (2007) 411-432.

R.J, Dalton, Citizen Politics: Public Opinion and Political Parties in Advanced Industrial Democracies, Cq Press. (2013)

A, Kellman, Democracy Assistance in Practice: The Designing of a Political Party Training Program in the Republic of Kenya', MA thesis, University of the Witwatersrand, Johannesburg, (2004)

L, Mokgatlhe, and K, Molefe, The Directorate on Corruption and Economic Crime, (2008) In Transparency, Accountability \& Corruption in Botswana. Made Plain Communications, Cape Town

K, Matlosa, Political Parties in Southern Africa: The State of Parties and their Role in Democratization. (2007). International Institute for Democracy and Electoral Assistance.

M. G, Molomo, Democracy under siege: the Presidency and executive powers in Botswana. Pula: Botswana Journal of African Studies, 14(1) (2000)

D, Mpabanga, Office of the Ombudsman, (2008) In Transparency, Accountability \& Corruption in Botswana, Made Plain Communications, Cape Town

R, Mulgan, Holding Power to Account: Accountability in Modern Democracies, (2003 Basingstoke: Palgrave. G.A, O'Donnell, Horizontal Accountability in New Democracies. Journal of Democracy, 9(3) (1998) 112-126.

OECD, Taking systems approach to accountability in developing countries, in Accountability and Democratic Governance: Orientations and Principles for Development, OECD Publishing Paris. (2014)

H, Peter, and E, Authur, The Accountability of Power: Democracy and Governance in Modern Times, European Political Science Review: EPSR. 4(2) (2012) 177-194.

S.A, Samarasinghe, Series on Democracy and Health. Democracy and Democratization in Developing Countries. Data for Decision Making Project Department of Population and International Health Harvard School of Public Health Boston, Massachusetts, (1994)

P.C, Schmitter, Political Accountability in 'Real-Existing' Democracies: Meaning and Mechanisms. European University Institute, (2007)

D, Sebudubudu, and B.Z, Osei-Hwedie, Pitfalls of parliamentary democracy in Botswana. Africa Spectrum, (2006) 35-53.

R, Speijcken, Strengthening the roles of Political Parties in Public Accountability. A case study of a new approach in Political Party Assistance in Kenya. International Institute for Democracy and Electoral Assistance (International IDEA) (2011) 